\title{
Agrophysical and Biological Properties of Drainage Soils in Land Reclamation
}

\author{
Yu. I. Mitrofanov ${ }^{1} \&$ G. Yu. Rabinovich ${ }^{1}$ \\ ${ }^{1}$ Federal State Budgetary Scientific Institution, All-Russian Research Institute of Reclaimed Lands, Tver, Russia \\ Correspondence: G. Yu. Rabinovich, Federal State Budgetary Scientific Institution, All-Russian Research \\ Institute of Reclaimed Lands, Tver 170530, Russia. E-mail: gur_u@mail.ru; vniimz@list.ru
}

Received: August 28, 2017

Accepted: September 28, $2017 \quad$ Online Published: October 15, 2017

doi:10.5539/jas.v9n11p259

URL: https://doi.org/10.5539/jas.v9n11p259

\begin{abstract}
This paper presents the results of the research carried out in the All-Russian Research Institute of Reclaimed Lands. It has been established that land improvement techniques increased the integral index of physical soil conditions from $0.41-0.60$ to $0.80-0.86$. The soil demonstrated a greater total number of microorganisms, as well as certain physiological groups such as actinomycetes, autochthonous and especially nitrogen-fixers; but the number of fungi and denitrifiers, as well as the fungi causing the Fusarium wilt of the plants, decreased.

Average crops increase achieved with the help of deep reclaiming band tillage of drained gleyish soil to depth $50-60 \mathrm{~cm}$ was $9.0-24.1 \%$ in both wet and dry years. This land improvement technique effect lasts for two-three years or longer. The ridged plowing compared to the ordinary plowing raised the spring crops by $0.55-0.61$ ton/ha (by 16.9-17.5\%) without making any additional expenditures.
\end{abstract}

Keywords: deep land-improving tillage, ridged plowing, soil microorganisms, nitrogen turnover, crop yield

\section{Introduction}

Preservation and reproduction of soil fertility is a global problem, since it has a direct bearing on food security for the whole world. It is generally recognized that the fertility of soils is formed under the influence of a complex of properties. In the humid zone of Russia, it is most often judged on the effective fertility of soils on crop yields, the content of readily hydrolyzable and mineral nitrogen, available phosphorus, exchangeable potassium, as well as certain types of microelements, etc. In this connection, the role of agrophysical and biological factors in the management of soil processes is to a much lesser extent. However, their role in the formation of effective fertility is often leading, especially on waterlogged and insufficiently drained soils (Mitrofanov et al., 2014, 2015, 2016; Moiseev, 2011). The main criteria characterizing the agrophysical factors of soil fertility include the lowest moisture capacity, available moisture reserves, water permeability, density of aggregation, penetration resistance, total porosity, aeration porosity, etc (Kiryushina \& Ivanova, 2005; Bondarev, 1994; Kuznetsova, 1990; Maslov, 1979; Mitrofanov, 2012; Revut, 1968; Blokhuis, 2006). In addition, objective diagnosis of the agrophysical state of soils should be supplemented with biological criteria of soil fertility (Goncharov et al., 2008; Moiseev, 2011; Rabinovich, 1991; Rabinovich \& Mitrofanov 2016; Wilson et al., 2013).

At the present time, agrophysical assessment of soils according to individual criteria is carried out on the basis of classification grades, established experimentally. To assess the physical state of the soil, complex indices were proposed-indices of the physical state of the soil, reflecting the basic agrophysical properties of the soil, which make it possible to characterize soil fertility in part of its physical component, not by individual properties of the soil, but as a whole. Of the individual diagnostic indicators, soil density, penetration resistance, total porosity, wilting humidity of plants, and minimum moisture capacity are used. Of the individual diagnostic indicators, soil density, penetration resistance, total porosity, wilting humidity of plants, and the lowest moisture capacity are used. The correlation coefficients of the indices of the agrophysical soil state with crop yields in some studies are 0.96-0.98 (Moiseev, 2011). The objectivity of the indices was confirmed by our studies of the effective fertility of drained gleyish sod-podzol soil of light loamy granulometric composition. The highest index (as the arithmetic average of the individual indices) was found in automorphic and slightly gley drained soils. Further, a consistent decrease in the index parameters was observed with increasing gleying of the drained soil. The yield of cereals and potatoes was in direct connection with complex indices reflecting the physical state of soils (Mitrofanov et al., 2015, 2016). 
The main methods of optimization and regulation of agrophysical and biological properties of soils in intensive farming are soil cultivation at different depths, improvement of the humus condition of soils, and complex meliorative measures. In wetlands, a radical method of improving the condition of soils is their draining by closed drainage, the water-regulating effect of which can be improved by applying a diversified land-improvement techniques-land-improving tillage, slit, surface planning, narrow-band plowing and other. Low-water-permeability soils and grounds demand the land-improving techniques as a necessary addition to using engineering drainage systems (Kizyaev et al., 2013; Maslov, 1979; Anonymous, 2003; Balchyunas et al., 1975; Chernenok et al., 1987; Zaidel'man, 2016; Twomlow et al., 1994).

A land-improving tillage of soils to the depths of $50-80 \mathrm{~cm}$ is the most significant land-improving technique for coarse grain-size soils (clayey and loamy), as well as soils that are light but have dense horizons or are underlaid by a low-water-permeability parent rock at a shallow depth. Large-scale research by The All-Russian Research Institute of Reclaimed Lands done in 1985-1995 and 2010-2016 showed that the deep land-improving tillage is a most effective technique to improve the physical water properties of the soil, strengthen the water control function of the drainage, optimize the water-and-air regime and conditions for growing the crops. In growing the spring crops, a special attention is paid to the ridged plowing used in the system of autumn plowing. The soil surface profiling is done to provide a more regular drying of the soil in spring, its earlier high-plastic state and physical maturity, a higher-quality sowing, better water-and-air regime, and finally creating more favorable conditions for the physical, chemical and biological processes occurring in the soil (Mitrofanov et al., 2015, 2016).

\section{Methods}

The field experiments on land-improving tillage and ridged plowing were performed by the generally accepted procedure (Dospekhov, 1985). The effectiveness of the land-improving tillage was studied in three field experiments at two land-improvement sites.

The first experiment (that revealed the role of the land-improving tillage as a major land-use technique) was done in a gleyish light-loamy sod-podzol soil underlaid by a carbonate moraine. A very dense layer $(22-147 \mathrm{~cm})$ of medium and heavy loams lay under the plowing soil layer of 20-22 cm. Water source was the atmosphere. Before starting the experiment the plowing soil layer had the following characteristics: the humus content was $2.48 \%$, salt extract $\mathrm{pH}-6.4$, hydrolytic acidity $-0.69 \mathrm{mg}$-equivalent parts $/ 100 \mathrm{~g}$, sum of bases - mg-equivalent parts $/ 100 \mathrm{~g}, \mathrm{P}_{2} \mathrm{O}_{5}-138 \mathrm{mg} / \mathrm{kg}, \mathrm{K}_{2} \mathrm{O}-57 \mathrm{mg} / \mathrm{kg}$; the equilibrium and critical bulk masses of the plowing soil layer at the experiment site reached $1.41 \mathrm{~g} / \mathrm{cm}^{3}$ and $1.32 \mathrm{~g} / \mathrm{cm}^{3}$ respectively; its density was $2.60 \mathrm{~g} / \mathrm{cm}^{3}$; the minimum moisture capacity (MMC) of the plowing soil layer was $26.0 \%$ of the soil mass; the filtration coefficient from the surface was $0.39-0.53 \mathrm{~m} /$ day (the average was 0.46 ), the filtration coefficient from the depth of $20-22 \mathrm{~cm}$ was $0.20-0.26 \mathrm{~m} /$ day (the average was 0.23 ).

Experiment 2 studied interactions among the land-improving tillage, fertilizing and basic tillage techniques. The experiment site soil was gleyish sod medium-podzol light-loamy. The plowing soil layer was $23-25 \mathrm{~cm}$-thick. The water source was the atmosphere. Before starting the experiment the plowing soil layer had the following characteristics: the humus content was $2.25 \% ; \mathrm{pH}-5.5-6.5 ; \mathrm{P}_{2} \mathrm{O}_{5}-152-184 \mathrm{mg} / \mathrm{kg} ; \mathrm{K}_{2} \mathrm{O}-58-85 \mathrm{mg} / \mathrm{kg}$; saturation with bases-92-95\%, density-2.62 $\mathrm{g} / \mathrm{cm}^{3} ; \mathrm{MMC}-26.7 \%$ of the soil mass; filtration coefficient $-0.26-0.38 \mathrm{~m} /$ day.

The third, landscape experiment with the land-improving tillage was carried out on the territory typical for final moraine landscapes that has a complex-structure soil covering a thin couple of sod low- and medium-podzol different-gley-content light-loamy and sandy-loamy soils. The tillage zone contained contours of surface- and profile-gley soils (slope bottom), gleyish (medium) soils, low-gley-content and amorphous soils (top relief elements). The plowing soil layer $(20-22 \mathrm{~cm})$ lay on the sandy-loam horizon $\mathrm{A}_{2}(20-42 \mathrm{~cm})$. Basic agrochemical characteristics of the plowing soil layer before starting the experiment were: $\mathrm{pH}-6.6 ; \mathrm{K}_{2} \mathrm{O}$ content $-201 \mathrm{mg} / \mathrm{kg}$; $\mathrm{P}_{2} \mathrm{O}_{5}-222 \mathrm{mg} / \mathrm{kg}$; hydrolytical acidity-1.68 mg-equivalent parts $/ 100 \mathrm{~g}$. The filtration coefficients of the plowing soil layer and moraine were $0.07-0.24$ and $0.34-0.48 \mathrm{~m} /$ day respectively.

The experiments were conducted in field crop-change rotation. The winter rye was preceded by annual grass crops, spring crops followed the winter rye, potatoes, perennial herbs. The land-improving tillage was a strip (band) one, 50-60 cm-deep. The tillage interval was $1.4 \mathrm{~m}$. In the crops rotation, the tillage was done for the annual grass crops (in the land improvement: a fallow), potatoes, barley.

In the ridged plowing experiments, our efforts were focused on a gleyish sod-podzol light-loamy soil containing up to $2.0 \%$ of humus, increased content of accessible phosphor and exchangeable potassium, $\mathrm{pH}$ 5.5-6.0. In the crops rotation, barley and oats followed potatoes and lupine, respectively. The basic experimental variants to 
compare were plowing (reference) and 20-22 cm-deep ridged plowing. The reference ordinary plowing was done with a PLN-4-35 plow, the ridged plowing was conducted with the same-model plow, but equipped for these special purposes. The ridges were formed 21.7-24.8 cm-high, the gap between the neighboring ridge centers was $70.2-73.8 \mathrm{~cm}$. By spring the ridges lowered to $14.6-16.1 \mathrm{~cm}$-high. The ridgeness was $18.1 \%$ and $15.6 \%$ in autumn and spring (before the tillage) respectively. The ridging increased the evaporation surface area by $15-20 \%$.

The experiment-site drainage was made of tiles, the average distance between its 0.9-1.2-deep lines was $20 \mathrm{~m}$. the experimental variants were placed systematically or random, across the drain lines. The total area of the test zone in the land-improving tillage experiment was 1 ha (each variant occupying a separate drain system). In the ridged plowing experiment, it was $200-400 \mathrm{~m}^{2}$, with 3-4 repeats, the analyzed area was $50-100 \mathrm{~m}^{2}$. Mineral fertilizers were added for the planned crops yield; the sowing rate was as generally accepted. The crops were harvested with a combine, the yield was recalculated for the standard $14 \%$ grain humidity. The harvest rise reliability was found by the variance analysis.

The effect of the land-improving tillage and ridged plowing on the water-and-air regime in the drained soil was evaluated using integral agrophysical characteristics such as soil physical state indices which are the arithmetical mean values of individual agrophysical indices. The following diagnostic criteria were used to calculate the physical state indices: total soil porosity, stable aeration porosity (the soil pore volume occupied by air in case of the minimum moisture capacity), soil moisture content (\% of the minimum moisture capacity) on the average for a vegetation period, and average vegetation period aeration coefficient $\left(\mathrm{C}_{\mathrm{a}}\right)$. They characterize the water-and-air regime parameters and show how many air units match a water volume unit in the soil, etc. these criteria were established to be directly related to the major field crops yield (Mitrofanov, 2012, 2015; Moiseev, 2011; Revut, 1968). Minimum, optimum and actual parameters of the above criteria were used in the calculations.

To study the activity of the soil microorganism community and trends in the biological events that occur in the soil, we used both field and laboratory methods for evaluation of the quantitative and qualitative composition of the soil microorganisms by growing the microorganisms on special media (Zvyagintsev, 1991). To evaluate the total amount of the microorganisms (TM), we used either an agarized soil extract (ASE, promoting growth of many various microorganisms, but mostly oligotrophic soil ones) or an ammonium starch agar (ASA).

\section{Results and Discussion}

The research showed that the land-improving tillage to the depth of 50-60 $\mathrm{cm}$ lowered the bulk mass of the plowing soil layer for its first year by $0.09 \mathrm{~g} / \mathrm{cm}^{3}$, under the plowing soil layer by $0.08 \mathrm{~g} / \mathrm{cm}^{3}$, and plowing soil layer self-packing rate lowered more than two-fold. There, the total porosity (average for a vegetation period) relative to the reference rose by $6.5 \%$, stable-aeration porosity increased by 37.6 , productive moisture resources by $12.0 \%$, aeration coefficient-two-fold, water permeability-3.2-fold. The integral index of physical soil conditions there rose more than two-fold, from 0.41 to 0.86 (Table 1). The land-improving tillage transferred the soil from physically a medium-cultured group to a well-cultured one. The nine-years average harvest increase due to the 50-60 cm-deep land-improving strip tillage of the gleyish soil being dried was $9.0-24.1 \%$, including $0.56 \mathrm{ton} / \mathrm{ha}, 0.30 \mathrm{ton} / \mathrm{ha}, 0,58 \mathrm{ton} / \mathrm{ha}$ and 5.70 ton/ha for winter rye, barley, oats and potatoes, respectively. The high effect of the land-improving tillage was observed in both wet and dry years. The tillage effect on the rotation crop yield persists within two, three or more years.

Essentially, our research showed that the land-improving tillage has a strong effect on the rate and trend of the biological events in the soil. In experiment 1 , the first year of the grain forage crops tillage intensified cellulose decomposition by $10.4-17.2$ and $7.7-9.1 \%$ in the plowing soil layer and plow-pan, respectively. That positive effect of the tillage on the cellulose-decomposition ability of the soil lasted for several years. In the third year after the tillage (an oats aftereffect), linen cloth decomposition in the plowing soil layer with the land-improving tillage was by $6.3 \%$ greater than in the reference, and the fourth year (barley) and the fifth year (perennial herbs) results were $6.5 \%$ and $6.3 \%$ higher, respectively. The positive trend was also observed in the plow-pan. Similar results were obtained in Experiment 3. The linen cloth decomposition rate with tillage was 14.0-28.6\% higher for all crops.

The above results are substantiated by growing microorganisms on special media (Rabinovich, 1991). In Experiment 2, averaged for five analyses within a vegetative period, the amount of the aerobic cellulose-decomposing bacteria in case of the land-improving tillage increased from the reference by $17.8 \%$ and $8.8 \%$ in the plowing soil layer and plowing-pan, respectively. At the same time, the land-improving tillage had a directly opposite effect on the number of the anaerobic cellulose-decomposing bacteria. Their amount in the 
plowing soil layer and plow-pan lowered from 0.26 to 0.14 thousand/g of absolutely dry soil (by $46.2 \%$ ) and from 0.48 to 0.29 thousand/g of soil (by $39.6 \%$ ), respectively.

Moreover, land-improving tillage for the winter rye showed the following effects in the plowing soil layer: elevated total quantity of microorganisms and actinomycetes, but lowered the total number of fungi by $98.0 \%$, $15.2 \%$ and $19.3 \%$, respectively (Table 1). The number of the microscopic fungi was at the level of 8.4-10.4 and 4.8-7.6 thousand cells in one gram of absolutely dry soil of the plowing soil layer and plow-pan, respectively. The number of the fungi in the plowing soil layer decreased by $36.9 \%$ thanks to the land-improving tillage. At some vegetation stages, the land-improving tillage increased the carbon dioxide release more than twice, compared to the reference. We established correlation between the soil-released carbon dioxide amount and the crop yield - their average correlation coefficient reached $65 \%$.

Table 1 . The effect of the land-improving tillage on the agrophysical and biological conditions in the gleyish soil and crop yields

\begin{tabular}{|c|c|c|c|c|}
\hline \multirow[b]{2}{*}{ Characteristics } & \multicolumn{2}{|c|}{$\begin{array}{l}\text { Actual values of criteria for } \\
\text { experimental variants }\end{array}$} & \multicolumn{2}{|c|}{ Compared to reference: } \\
\hline & $\begin{array}{l}20-22 \mathrm{~cm} \\
\text { plowing - } \\
\text { reference }\end{array}$ & $\begin{array}{l}20-22 \mathrm{~cm} \\
\text { plowing }+50-60 \mathrm{~cm} \\
\text { land-improving tillage }\end{array}$ & \pm & $\%$ or ...-fold \\
\hline Integral index of physical soil conditions & 0.41 & 0.86 & +0.45 & 2.1-fold \\
\hline \multicolumn{5}{|l|}{ Criteria and parameters of the biological activity of the soil (plowing soil layer) } \\
\hline Linen cloth decomposition, $\%$ & 41.6 & 58.8 & +17.2 & 141.3 \\
\hline Cellulose-decomposing & $4.5 / 0.26$ & $5.3 / 0.14$ & $+0.8 /-0.12$ & $117.8 / 53.8$ \\
\hline $\begin{array}{l}\text { microorganism, aerobes/anaerobes } \\
\text { Total number of microorganisms } \\
\text { on agarized soil extract }\end{array}$ & 97.0 & 192.0 & +95 & 198.0 \\
\hline Actinomycetes & 14.5 & 16.7 & +2.2 & 115.2 \\
\hline Microscopic fungi & 10.4 & 8.4 & -2.0 & 80.7 \\
\hline $\mathrm{CO}_{2}$ released, $\mathrm{kg} / \mathrm{ha} / \mathrm{hour}$ & 3.98 & 6.59 & +2.61 & 165.6 \\
\hline Catalase activity, $\mathrm{cm}^{3} \mathrm{O}_{2} / \mathrm{g} /$ minute & 2.05 & 2.55 & +0.50 & 124.4 \\
\hline Dehydrogenase activity, mg triphenylformazan/10 g/24 h & 2.00 & 1.41 & -0.59 & 70.5 \\
\hline \multicolumn{5}{|l|}{ Crops yield, ton/ha } \\
\hline Winter rye & 3.92 & 4.48 & +0.56 & 114.3 \\
\hline Barley & 3.34 & 3.64 & +0.30 & 109.0 \\
\hline Oats with clover & 3.18 & 3.76 & +0.58 & 118.2 \\
\hline Potatoes & 24.5 & 30.4 & +5.7 & 124.1 \\
\hline
\end{tabular}

An enzymatic activity is the crucial diagnostic indicator of the fertility and biological trends of the drained soil. The experimental sites soil catalase and dehydrogenase activities are medium- $\left(2-3 \mathrm{ml} \mathrm{O}_{2} / 1 \mathrm{~g}\right.$ of absolutely dry soil/1 minute) and low-level (0.5-2.5 mg triphenylformazan/10g of soil/24 hours) (Zvyagintsev, 1991). The land-improving tillage raised the catalase activity and lowered the dehydrogenase one, that is provided more active soil oxidation processes in more favorable water-and-air conditions. The tillage strengthened the catalase activity and weakened the dehydrogenase one in the plowing soil layer by $8.7-24.4 \%$ and $13.9-29.5 \%$, respectively (and the plow-pan dehydrogenase activity lowered by $4.5-63.0 \%$. The soil catalase content correlated with the carbon dioxide release, and the average correlation coefficient of those two parameters for certain crops reached 0.90 .

For the time period from the tillage till the physical spring ripeness, the soil density drift in the plowing soil layer was $0.15 \mathrm{~g} / \mathrm{cm}^{3}$ and $0.10 \mathrm{~g} / \mathrm{cm}^{3}$ (by $0.05 \mathrm{~g} / \mathrm{cm}^{3}$ less) in case of the ordinary and ridged plowing, respectively. That difference remained the same even after flattening the ridges. By the end of the vegetation period, the ordinary-plowed soil consolidated to its equilibrium state-its bulk mass exceeded the critical level by 0.04 $\mathrm{g} / \mathrm{cm}^{3}$, whereas the same exceeding in case of the ridged plowing was only $0.01 \mathrm{~g} / \mathrm{cm}^{3}$. The most significant lowering of the bulk mass of the soil was noticed in spring - before the tillage. 
The changes in the bulk mass and humidity regime of the soil lead to changes in its porosity and volume proportion of its solid, liquid and gaseous phases. In case of the ridged plowing, the total porosity of the soil in autumn and early spring was respectively by $1.6 \%$ and $2.1 \%$ higher, the aeration porosity was respectively by 7.8 and $9.9 \%$ higher than with the ordinary plowing. The ridged plowing shifted the soil water/air proportion to the values more favorable for plants and biological soil processes - to a better aeration of the plowing soil layer compared to the reference. The ridged plowing gave the soil water/air proportion of 1:1.56 in autumn, 1:1 in spring and summer; the season references were 1:0.94, 1:0.48, 1:0.85 respectively-that is the reference plowing soil layer aeration was substantially lower. The integral index of physical soil conditions was raised by the ridged plowing by $33.3 \%$ - from 0.60 to 0.80 (Table 2 ).

The ridged tillage effect on the microbiological processes was in increasing the total amount of microorganisms, as well as autochthonic ones, actinomycetes, and nitrogen-fixing microorganisms. During a vegetation period, the ridged tillage raised azotobacter and free-living anaerobic nitrogen-fixers contents 1.9 -fold and by $22.1 \%$, respectively. The ridged plowing elevated the quantity of the microorganisms using the mineral nitrogen by $13.2 \%$ compared to the ordinary plowing. Moreover, the ridging lowered the number of fungi and denitrifying microorganisms. Thanks to the more favorable soil aeration, the quantity of the denitrifiers in the plowing soil layer during the vegetation period fell down by $48.5 \%$. So, the ridged tillage sanified the soil. That is why the number of the microorganisms causing the Fusarium wilt lowered throughout the whole vegetation period of the forage grain crops.

On the average, the ridged tillage provided mineral nitrogen accumulation by $24.1 \%$ greater than an ordinary plowing, including ammonium- and nitrate-nitrogen increase by $16.0 \%$ and $32.5 \%$, respectively. It is significant that the ridged plowing promoted the nitrates accumulation during the time period when the plants consumed maximum nitrogen, that is at the stages of booting and earing. At those stages, the ridged tillage provided 14.7$40.4 \%$ more nitrate nitrogen than ordinary plowing.

The agroproduction effect of the autumn ridging was achieved thanks to prolongation of the vegetation period, optimization of the whole system of the spring field works, activation of the biological processes, more nitrogen for the plants, and more effective soil fertility as a whole. The gleyish soil ridging increased the barley and oats yields by 0.61 ton/ha (17.1\%) and 0.55 ton/ha (16.9\%), respectively (five-years average).

Table 2. The effect of the ridged plowing on the agrophysical and biological properties of the drained gleyish soil and spring grain crop yields

\begin{tabular}{|c|c|c|c|c|}
\hline \multirow{2}{*}{ Characteristics } & \multicolumn{2}{|c|}{$\begin{array}{l}\text { Actual values of criteria } \\
\text { for experimental variants }\end{array}$} & \multicolumn{2}{|c|}{ Compared to reference } \\
\hline & $\begin{array}{l}20-22 \mathrm{~cm} \\
\text { plowing - reference }\end{array}$ & $\begin{array}{l}20-22 \mathrm{~cm} \\
\text { ridged plowing }\end{array}$ & \pm & $\%$ or ...-fold \\
\hline Integral index of physical soil conditions & 0.60 & 0.80 & +0.20 & 133.3 \\
\hline \multicolumn{5}{|l|}{ Soil microorganisms community state (plowing soil layer) } \\
\hline Microscopic fungi & 11.4 & 10.0 & -1.4 & 87.7 \\
\hline Actinomycetes & 387 & 445 & +58 & 115.0 \\
\hline thousand/g of absolutely dry soil & 57.3 & 70.0 & +12.7 & 122.1 \\
\hline Denitrifiers & 161 & 83 & -78 & 51.5 \\
\hline Microorganisms causing Fusarium wilt & 23.7 & 15.4 & -12.3 & 65.0 \\
\hline $\begin{array}{l}\text { Total number of microorganisms on } \\
\text { ammonium starch agar }\end{array}$ & 16.2 & 16.7 & +0.5 & 103.7 \\
\hline Autochthonous microorganisms & 6.3 & 7.1 & +0.8 & 112.7 \\
\hline Ammonifying microorganisms & 2.6 & 2.5 & -0.1 & 96.1 \\
\hline Microorganisms using mineral $\mathrm{N}$ & 5.3 & 6.0 & +0.7 & 113.2 \\
\hline Azotobacter & 15.4 & 29.5 & +14.1 & 191.6 \\
\hline \multicolumn{5}{|l|}{ Forage grain crops yield, ton/ha } \\
\hline Barley & 3.56 & 4.17 & +0.61 & 117.1 \\
\hline Oats & 3.24 & 3.79 & +0.55 & 116.9 \\
\hline
\end{tabular}


The experiment we done on different soils showed that this technique provided the greatest barley yield increases (0.72-1.64 ton/ha) on the gley soils. In that experiment, the crop yield increased by 5.9 and 5.1 metric centners/ha on the gleyish and low-gley-content light-loamy soils. The ridged plowing had no effect on the barley yield on the low-gley-content sandy-loamy soil. The drained-soil ridged plowing gave the grain crops yield increase caused by more ear stems, more grains in the ear, and greater mass of 1000 grains. The ridged tillage increased the field germinability of the barley and oats, plant bushiness and biomass (at the stage of booting) by $2.3-7.4 \%, 0.2-0.4$ units and $16.2-33.8 \%$.

The land-improving tillage and ridged plowing-just like every technique of mechanical impact on the soil-have an effect, first of all, on the soil bulk density (bulk mass) and porous system that determines main functional properties of the soil: water permeability, moisture capacity, water-retaining capacity, air content, as well as processes of accumulation, transformation and consumption of the soil resources for plant life support. Here, the soil porosity is a function of many physical properties of the soil (structure state, bulk mass, solid phase density, swelling capacity, etc.). The soil pore space is most closely related to the bulk density (bulk mass) of the soil. The latter are among the crucial criteria determining the physical state of the soil medium, soil water, air-and-water and nutritional turnovers, plant moisture support, the type and trend of microbiological events, root system development, the level of effective fertility and productivity of the plant on the lands being dried (Bondarev, 1994; Kuznetsova, 1990; Mitrofanov, 2012, 2014; Revut, 1968).

The ridged plowing — just like the land-improving tillage — substantially changes the physical water state of the plowing soil layer in autumn, winter and early spring, lowers the drift and self-packing rates, continues its positive influence on the physical state of the soil during the crops vegetation period. First of all, the soil located in the shaped ridges gets dense slower than in case of a regular plow.

Evaluating the effects of the ridged tillage on the mineral nitrogen turnover under the plants throughout their whole vegetation period, it should be noted that it had the most significant effect on nitrates metabolism. The positive effect of the ridged plowing on the mineral nitrogen content in the soil was especially obvious on fallows. When there is no plants effect on the mineral nitrogen content in the soil, it mostly depends on microbiological processes.

Thus, the application of tillage of drained soils to a depth of 50-60 cm and ridged plowing is an effective way to optimize its agrophysical state, improve biological properties and increase effective fertility. Agromeliorative methods of soil cultivation should be considered as the most important elements of modern farming systems in humid climatic zones.

\section{Conclusion}

In the Russian Federation Nonblack Soil Zone, one of the main factors that restrict the agriculture productivity is a great number of overwetted agricultural lands. Our research has showed that the land-improving tillage and ridged plowing are both important techniques to improve the physical state of the drained mineral soils having poor filtration properties - and effective accelerators for microbiological activities in the soil, that accelerate predominantly aerobic soil microorganisms activities. The land-improving tillage and ridged plowing raised the integral index of physical soil conditions of the drained soil more than two-fold (from 0.41 to 0.86 ) and from 0.60 to 0.80 , respectively. The agricultural land-improving techniques elevated the total quantity of microorganisms, actinomycetes, autochthonous and especially nitrogen-fixing microorganisms in the soil. The quantity of soil azotobacter in case of the ridged plowing was 1.9-2.5-times greater than after an ordinary plowing. Moreover, the number of fungi (including those which cause the Fusarium wilt) and denitrifying microorganisms decreased. On the average, the nine years of the 50-60 cm-deep land-improving strip tillage of the drainage gleyish soil gave the crops yield increase by $9.0-24.1 \%$, including 0.56 ton/ha, 0.30 ton $/ \mathrm{ha}, 0.58$ ton/ha and 5.70 ton/ha for the winter rye, barley, oats and potatoes, respectively.

The high effectiveness of the land-improving tillage was noticed in both wet and dry years. The land-improving tillage effect on the rotation crops yield usually lasts for two-three or more years. The ridged plowing of the drainage gleyish sod-podzol light-loamy soil, compared to an ordinary plowing, allows (practically without any additional expenditures) raising the spring grain crops yield by $0.55-0.61$ ton/ha, at the same time lowering expenditures on the basic resources spent on the forage grain production.

\section{References}

Anonymous. (2003). Land Reclamation Encyclopedia (1st ed., p. 36). Moscow, RF: FGNU RosInformAgroTech. Retrieved from http://elib.ieek.timacad.ru/opac/index.php?url=/notices/index/IdNotice:7873/Source:default 
Balchyunas, A. I., Blazhis, B. I., Zelenka, L. P., et al. (1975). Experience on Land Drying by Underdrainage. Moscow, RF: Kolos Publishers. Retrieved from http://catalog.belstu.by/catalog/books/d/IDX245a/ view/72704

Blokhuis, W. (2005). Vertisols. Encyclopedia of Soil Science (2nd ed.). https://doi.org/10.1201/noe084933 8304.ch389

Bondarev, A. G. (1994). Theoretical Principles and Practice of Optimization of the Physical Conditions for Soil Fertility. Soil Science, 11, 10-15. Retrieved from http://elibrary.ru/item.asp?id=23468545

Chernenok, V. Ya., Pechenina, V. S., Balchyunas, A. I., et al. (1987). Recommendations on Drying Heavy Soils by Underdrainage with Applying Land Reclamation Operations and Chemical Land-Improvers. Moscow, RF. Retrieved from http://www.dissercat.com/content/razrabotka-konstruktsii-poglotitelnoi-kolonki-dlyadrenazha-promerzaemykh-slabovodopronitsae

Dospekhov, B. A. (1985). Field Experiment Method. Moscow, RF: Agropromizdat. Retrieved from http://www.bibliolink.ru/publ/10-1-0-184

Goncharov, V. M., Faustova, E. V., \& Tymbayev, V. G. (2008). A quantitative approach to a comprehensive assessment of soil cover. Bulletin of Tomsk State University, 315, 206-213. Retrieved from http://sun.tsu.ru/mminfo/000063105/315/image/315-206.pdf

Kiryushina, V. I., \& Ivanova, A. L. (2005). Agroecological assessment of lands, design of adaptive-landscape systems of agriculture and agro-technologies. Moscow: FGNU "Rosinfrpmagrotech". Retrieved from http://www.twirpx.com/file/487933

Kizyaev, B. M., Mamaev, Z. M., \& Pershina, O. F. (2013). Agricultural Measures for Land Reclamation on Mineral Overwetted Lands. Moscow, RF: VNIIA. Retrieved from http:/www.cnshb.ru/cnshb/newpost/ arttrn.asp?val=RUM0088616

Kuznetsova, I. V. (1990). About Optimum Soil Density. Soil Science, 5, 40-42. Retrieved from http://www.alib.ru/au-kuznecova/nm-optimalnmnnoj_plotnosti_pochv

Maslov, B. S. (1979). Deep Tillage: Experience and Science Tasks. Hydraulic Engineering and Land Improvement, 7, 28-33. Retrieved from http:/www.dissercat.com/content/tekhnologicheskie-osnovybestransheinogo-stroitelstva-zakrytykh-osushitelnykh-sistem-i-rykhl

Mitrofanov, Y. I., Anziferova, O. N., \& Pervushina, N. K. (2015). Agrophysical conditions and fertility of drained soils. Russian Agricultural Sciences, 41(6), 462-464. https://doi.org/10.3103/s1068367415060154

Mitrofanov, Y. I., Petrova, L. I., \& Antsiferova, O. N. (2016). Peculiarities of regulating the fertility of over-moistened soils. Bulletin of the Russian Agricultural Science, 5, 35-39. Retrieved from https://elibrary.ru/item.asp?id=26723279

Mitrofanov, Y. I., Rabinovich, G. Y., \& Kotelnikov, V. A. (2014). Change of biological activity of soils under the influence of ameliorative loosening. Russian Agricultural Sciences, 41(1), 26-29. https://oi.org/10.3103/ s1068367415010152

Mitrofanov, Yu. I. (2012). Density and Water-and-Air Dynamics of Drainage Soils. Land Reclamation and Water Industry, 1, 16-19. Retrieved from http://elibrary.ru/contents.asp?issueid=1014579

Moiseev, K. G. (2011). To Evaluation of the Physical State of the Sod-Podzol Soils. Agrophysics, 1, 38-43. Retrieved from http://www.agrophys.ru/Media/Default/Page/Agrophys_magazine/N1/Moiseev.pdf

Rabinovich, G. Yu. (1991). Effects of Tillage on Microorganisms and Biological Activity of the Dried Gleyish Sod-Podzol Soil on Thin Two-Component Sediments (PhD Thesis in Biological Sciences). Moscow, RF: Agricultural Academy. Retrieved from http://search.rsl.ru/ru/record/01008067349

Rabinovich, G., \& Mitrofanov, Y. (2016). Microorganisms and Nitrogen Turnover in the Soil Dried by Ridged Plowing. International Journal of Current Research, 8(04), 29063-29068. Retrieved from http:/www.journalcra.com/article/microorganisms-and-nitrogen-turnover-soil-dried-ridged-plowing

Revut, I. B. (1968). Soil Density and Fertility. Collected Works: Theoretical Issues of Soil Tillage. Leningrad, USSR: Gidrometeoizdat Publishers. Retrieved from http://www.dissercat.com/content/vliyaniemnogoletnikh-bobovykh-trav-na-agrofizicheskie-svoistva-i-plodorodie-pochvy-v-razlic 
Twomlow, S. J., Parkinson, R. J., \& Reid, I. (1994). Temporal changes in soil physical conditions after deep loosening of a silty clay loam in SW England. Soil and Tillage Research, 31(1), 37-47. https://doi.org/10.1016/0167-1987(94)90093-0

Wilson, M. G., Sasal, M. C., \& Caviglia, O. P. (2013). Critical bulk density for a Mollisol and a Vertisol using least limiting water range. Geoderma, 192, 354-361. https://doi.org/10.1016/j.geoderma.2012.05.021

Zaidel'man, F. R. (2016). Deep reclamation loosening of soils: State of the problem, results of research, prospects of application, and degradation changes. Eurasian Soil Science, 49(9), 1061-1074. https://doi.org/10.1134/s1064229316070139

Zvyagintsev, D. G. (1991). Methods in Soil Microbiology and Biochemistry. Moscow, RF: Moscow State University Publishers. Retrieved from http://www.pochva.com/?content=3\&book_id=0128

\section{Copyrights}

Copyright for this article is retained by the author(s), with first publication rights granted to the journal.

This is an open-access article distributed under the terms and conditions of the Creative Commons Attribution license (http://creativecommons.org/licenses/by/4.0/). 